\title{
Feeding and grazing impact of the newly described heterotrophic dinoflagellate Stoeckeria algicida on the harmful alga Heterosigma akashiwo
}

\author{
Hae Jin Jeong ${ }^{1, *}$, Jae Seong Kim², Jong Hyeok Kim ${ }^{3}$, Seong Taek Kim ${ }^{3}$, \\ Kyeong Ah Seong ${ }^{3}$, Tae Hoon Kim ${ }^{3}$, Jae Yoon Song ${ }^{3}$, Soo Kyeum Kim ${ }^{3}$ \\ ${ }^{1}$ School of Earth and Environmental Sciences, and ${ }^{2}$ Research Institute of Oceanography, College of Natural Sciences, \\ Seoul National University, Seoul 151-742, Korea \\ ${ }^{3}$ Department of Oceanography, College of Ocean Science and Technology, Kunsan National University, Kunsan 573-701, Korea
}

\begin{abstract}
To investigate the roles of the newly described thecate heterotrophic dinoflagellate Stoeckeria algicida (GenBank accession number = AJ841809), which was abundant during the red tides dominated by the harmful raphidophyte Heterosigma akashiwo, we measured the abundances of $H$. akashiwo and S. algicida in Masan Bay, Korea, from May to July 2004. We also measured growth and ingestion rates of $S$. algicida when feeding on $H$. akashiwo in the laboratory. Grazing coefficients were calculated by combining field data on abundances of $S$. algicida and co-occurring $H$. akashiwo with laboratory data on ingestion rates obtained in the present study. The maximum abundances of $H$. akashiwo during $2 H$. akashiwo red tides were 58400 and 99200 cells ml, while

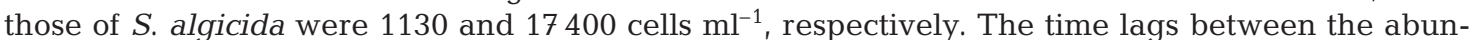
dance peaks of $H$. akashiwo and $S$. algicida in these red tide periods were 1 to $2 \mathrm{~d}$. $S$. algicida fed on $H$. akashiwo using a peduncle after anchoring the prey by a tow filament. Specific growth rates of $S$. algicida increased rapidly with increasing mean prey concentration before saturating at H. akashiwo concentrations of ca. $350 \mathrm{ng} \mathrm{C} \mathrm{ml}^{-1}\left(3500\right.$ cells ml $\left.\mathrm{m}^{-1}\right)$. The maximum specific growth rate of $S$. algicida on $H$. akashiwo was $1.63 \mathrm{~d}^{-1}$. The threshold prey concentration (where net growth $=0$ ) was $1.9 \mathrm{ng} \mathrm{C} \mathrm{ml} \mathrm{m}^{-1}\left(19\right.$ cells $\left.\mathrm{ml}^{-1}\right)$. Maximum ingestion and clearance rates of $S$. algicida on H. akashiwo were $0.75 \mathrm{ng}$ C grazer ${ }^{-1} \mathrm{~d}^{-1}$ (7.5 cells grazer ${ }^{-1} \mathrm{~d}^{-1}$ ) and $3.7 \mu$ grazer ${ }^{-1} \mathrm{~h}^{-1}$, respectively. Calculated grazing coefficients for $S$. algicida on $H$. akashiwo were up to $0.142 \mathrm{~min}^{-1}$ (i.e. $13 \%$ of $H$. akashiwo populations were removed by a $S$. algicida population in $1 \mathrm{~min}$ ). The results of the present study suggest that $S$. algicida sometimes has a considerable grazing impact on populations of H. akashiwo.
\end{abstract}

KEY WORDS: Food web · Harmful algal bloom $\cdot$ Ingestion $\cdot$ Peduncle $\cdot$ Protist $\cdot$ Red tide

\section{INTRODUCTION}

The red tide phenomenon, discoloration of the surface of the sea due to plankton blooms, can alter the balance of food webs and cause large-scale mortalities of fish and shellfish (ECOHAB 1995). Studies of red tide formation and persistence suggest that grazing pressure may play an important role in bloom dynamics (Watras et al. 1985). In particular, grazing by microzooplankton is believed to contribute to the decline of red tides (Holmes et al. 1967, Eppley \& Harrison 1975, Jeong 1995, 1999, Kamiyama et al. 2000, Stoecker \& Gustafson 2002, Johnson et al. 2003, Tillmann 2004, Kim \& Jeong 2004).

The raphidophyte Heterosigma akashiwo can cause large-scale fish mortality rates when abundant during red tides (MacKenzie 1991, Chang et al. 1993, Honjo 1993, Imai et al. 1996). Its density sometimes exceeds 100000 cells ml ${ }^{-1}$ during red tides (e.g. Nagasaki et al. 1996). The clogging of fishes' gills by $H$. akashiwo may 
be mainly responsible for the mortality rates as there have been no reports on the existence of a $H$. akashiwo toxin. Only a few heterotrophic protists are known to feed on $H$. akashiwo, e.g. the heterotrophic dinoflagellates Gyrodinium dominans and Oxyrrhis marina, and the prostomatid ciliate Tiarina fusus (Nakamura et al. 1995, Jeong et al. 2002, 2003). However, large tintinnid ciliate Favella spp. did not ingest this prey (Taniguchi $\&$ Takeda 1988) or the ingestion rate was undetectable even though this prey was ingested in the initial incubation (Kamiyama \& Arima 2001). We found that the newly described thecate heterotrophic dinoflagellate Stoeckeria algicida was often the most dominant heterotrophic protist during red tides dominated by H. akashiwo in Masan Bay, Korea, and that the grazer was able to grow well on this red tide prey. However, no study has reported the feeding mechanism, and growth and grazing rates of $S$. algicida on $H$. akashiwo as a function of prey concentration, nor has anyone studied its grazing impact on the prey.

To understand the role of Stoeckeria algicida in the dynamics of Heterosigma akashiwo, we measured the abundances of $H$. akashiwo and S. algicida in Masan Bay, Korea, established a monoclonal culture of $S$. algicida, examined feeding behavior, and conducted experiments to examine its numerical and functional responses when grown on $H$. akashiwo. We also estimated grazing coefficients attributable to $S$. algicida on $H$. akashiwo by combining field data on abundances of $S$. algicida and co-occurring $H$. akashiwo with laboratory data on ingestion rates obtained in the present study.

Maximum growth and grazing rates of Stoeckeria algicida on Heterosigma akashiwo were compared to those of other heterotrophic protists feeding on the same prey species. The results of the present study provide a basis for understanding the potential of $S$. algicida to influence the population dynamics of $H$. akashiwo.

\section{MATERIALS AND METHODS}

Abundances in Masan Bay, Korea. Water samples were taken from the surface during red tides dominated by Heterosigma akashiwo from May to July 2004 at a pier in Masan Bay. Samples were taken at 10:00 h using water samplers, and sometimes additional samples were taken at 16:00 $\mathrm{h}$ on the same day. Plankton samples for counting were poured into $500 \mathrm{ml}$ polyethylene bottles and preserved with acidic Lugol's solution. After being well mixed, all or $>300$ Stoeckeria algicida and $H$. akaskiwo cells were counted under an inverted microscope with standard transmitted illumination in three $1 \mathrm{ml}$ Sedgwick-Rafter counting chambers (SRCs).
Water temperatures and salinities in the surface waters were measured using a YSI 30 (YSI Incorporated) and $\mathrm{pH}$ and dissolved oxygen (DO) concentration were measured using pH-11 (Schott Handy - Lab) and Oxi 197i (WTW), respectively.

Culture of phytoplankton prey. Heterosigma akashiwo was grown at $20^{\circ} \mathrm{C}$ in enriched $\mathrm{f} / 2$ seawater media (Guillard \& Ryther 1962) without silicate, under continuous illumination of $100 \mu \mathrm{E} \mathrm{m}{ }^{-1} \mathrm{~s}^{-1}$ provided by cool white fluorescent lights. Only cultures in an exponential growth phase were used for feeding experiments. The carbon content for $H$. akashiwo $(0.1 \mathrm{ng} \mathrm{C}$ cell $\left.^{-1}, \mathrm{n}_{3}>2000\right)$ was estimated from cell volume $\left(700 \mathrm{~mm}^{3}\right)$ according to Strathmann (1967).

Isolation and culture of Stoeckeria algicida. Plankton samples collected with water samplers were taken from a pier in Masan Bay, Korea, during July 2004 when the water temperature and salinity were $24.8^{\circ} \mathrm{C}$ and $20.6 \mathrm{psu}$, respectively. The samples were gently screened through a $154 \mu \mathrm{m}$ Nitex mesh and placed in 6-well tissue culture plates and a monoclonal culture of $S$. algicida was established by 2 serial single cell isolations. As the concentration of $S$. algicida feeding on Heterosigma akashiwo increased, the grazers were subsequently transferred to 32,270 , and $500 \mathrm{ml}$ polycarbonate (PC) bottles of fresh H. akashiwo. The bottles were again filled to capacity with freshly filtered seawater, capped, and placed on a rotating wheel at $0.9 \mathrm{rpm}$ at $20^{\circ} \mathrm{C}$ under an illumination of $20 \mu \mathrm{E} \mathrm{m} \mathrm{m}^{-2} \mathrm{~s}^{-1}$ of cool white fluorescent light on a 12:12 h light:dark cycle. Once dense cultures of $S$. algicida (8000 to 10000 cells ml$^{-1}$ ) were obtained, they were transferred to $500 \mathrm{ml}$ PC bottles of fresh prey (ca. 30000 cells ml$^{-1}$ ) every day. Experiments were conducted when large volumes of $S$. algicida culture were available. The carbon content for $S$. algicida was estimated from cell volume (see next subsection) according to Menden-Deuer \& Lessard (2000).

Stoeckeria algicida is similar to Pfiesteria piscicida and some Pfiesteria-like species in size and shape, but the plate pattern (Po, cp, X, 4', 2-3a, 7", 6c, 6s, 5"', and $2^{\prime \prime \prime \prime}$ in a Kofoidian series) and the sequence of SSU rDNA of $S$. algicida (GenBank accession number = AJ841809) are markedly different from those of $P$. piscicida (Po, cp, X, 4', 1a, 5", 6c, 4s, 5"', and 2"'"' in a Kofoidian series; GenBank accession numbers = AF218805, AF080098) and Pfiesteria-like species (Jeong et al. 2005).

Cell volume. Cell length and maximum width of Stoeckeria algicida preserved in 5\% acidic Lugol's solution $(\mathrm{n}=30)$ were measured using a compound or inverted microscope. The shape of $S$. algicida was estimated as being oval. The cell volume of preserved $S$. algicida was calculated according to the equation: volume $=4 / 3 \times \pi[(\text { cell length }+ \text { cell width }) / 4]^{3}$. 
Feeding process. A culture of Stoeckeria algicida starved for $24 \mathrm{~h}$ was transferred to a 6-well-plate chamber containing a dense culture of Heterosigma akashiwo. The feeding behavior of $>50$ unfed $S$. algicida cells was then observed under a dissecting microscope at a magnification of $50 \times$. Some $S$. algicida cells capturing prey cells were placed on slides using a micropipette, cover-glasses were added, and then a series of pictures of $S$. algicida at several different stages of the feeding process were taken using an Olympus digital camera on a compound microscope at a magnification of 100 to $400 \times$.

Growth and ingestion rates. This experiment was designed to measure growth, ingestion, and clearance rates of Stoeckeria algicida, as a function of the prey concentration, when feeding on Heterosigma akashiwo (Table 1).

Three days before these experiments were conducted, dense cultures (10000 to 12000 cells ml$^{-1}$ ) of Stoeckeria algicida growing on Heterosigma akashiwo were transferred into new $500 \mathrm{ml}$ PC bottles of fresh prey (ca. 1000 cells $\mathrm{ml}^{-1}$ ) every day. This was done to make the growth rate of $S$. algicida almost zero at the end of this pre-incubation. The bottles were filled to capacity with filtered seawater and placed on a rotating wheel to incubate as above. The abundances of $S$. algicida and prey were determined by enumerating cells in three $1 \mathrm{ml}$ SRCs.

The initial concentrations of Stoeckeria algicida and Heterosigma akashiwo were established using an autopipette to deliver predetermined volumes of known cell concentrations to the bottles. Triplicate $80 \mathrm{ml} \mathrm{PC}$

Table 1. Stoeckeria algicida feeding on Heterosigma akashiwo. Estimation of grazing impact by a $S$. algicida population on a H. akashiwo population using the equations in Fig. 4 derived from the laboratory experiments and the abundances of co-occurring $H$. akashiwo and $S$. algicida obtained from water samples collected off Masan Bay in 2004. HaC: $H$. akashiwo concentration; SaC: S. algicida concentration; SaPIR: S. algicida population ingestion rate; Sag: $S$. algicida grazing coefficient. Ingestion rates were corrected using $Q_{10}=2.8$ (Hansen et al. 1997) because in situ water temperatures and the temperature used in the laboratory for this experiment $\left(20^{\circ} \mathrm{C}\right)$ were different

\begin{tabular}{|cccc|}
\hline $\begin{array}{c}\mathrm{HaC} \\
\left(\text { cells ml }^{-1}\right)\end{array}$ & $\begin{array}{c}\mathrm{SaC} \\
\left(\text { cells ml }^{-1}\right)\end{array}$ & $\begin{array}{c}\text { SaPIR } \\
\left(\text { prey ml }^{-1} \mathrm{~h}^{-1}\right)\end{array}$ & $\begin{array}{c}\text { Sag } \\
\left(\mathrm{h}^{-1}\right)\end{array}$ \\
\hline 17 & 69 & 1 & 0.070 \\
45 & 3300 & 174 & 4.000 \\
700 & 17400 & 5546 & 8.500 \\
1130 & 310 & 82 & 0.075 \\
4800 & 8300 & 3861 & 1.631 \\
10300 & 1130 & 409 & 0.040 \\
29500 & 510 & 178 & 0.006 \\
41000 & 505 & 439 & 0.011 \\
99200 & 3700 & 2015 & 0.021 \\
\hline
\end{tabular}

experiment bottles (containing mixtures of predator and prey) and triplicate control bottles (containing prey only) were set up for each predator-prey combination. Triplicate control bottles containing only $S$. algicida were also established at 1 predator concentration. Ten $\mathrm{ml}$ of $\mathrm{f} / 2$ medium were added to all bottles, which were then filled to capacity with freshly filtered seawater and capped. To determine actual predator and prey concentrations at the beginning of the experiment and after 24, 48 , and $72 \mathrm{~h}$ of incubation, a $5 \mathrm{ml}$ aliquot for $S$. algicida was removed from each bottle and fixed with $5 \%$ Lugol's solution, and all predator cells and all or $>200$ prey cells were enumerated in three $1 \mathrm{ml}$ SRCs. The ranges of the actual prey and predator concentrations in the experimental bottles at the beginning of the experiment were 23 to 31263 and 9 to 121 cells ml $^{-1}$, respectively. The actual predator concentration in the control bottles containing only $S$. algicida was 98 cells $\mathrm{ml}^{-1}$. Prior to taking subsamples, the condition of $S$. algicida and its prey was assessed using a dissecting microscope. The bottles were again filled to capacity with freshly filtered seawater, capped, and placed on a rotating wheel at $0.9 \mathrm{rpm}$ at $20^{\circ} \mathrm{C}$ under an illumination of $20 \mu \mathrm{E} \mathrm{m}^{-2} \mathrm{~s}^{-1}$ of cool white fluorescent light on a $12: 12 \mathrm{~h}$ light:dark cycle. Dilution of the cultures associated with refilling the bottles was considered in calculating growth and ingestion rates.

The specific growth rate of Stoeckeria algicida, $\mu\left(\mathrm{d}^{-1}\right)$, was calculated by averaging the instantaneous growth rates (IGR) for each sampling interval, calculated as:

$$
\mathrm{IGR}=\frac{\ln \left(S_{t_{2}} / S_{t_{1}}\right)}{t_{2}-t_{1}} \times 24
$$

where $S_{t_{1}}$ and $S_{t_{2}}$ are the concentrations of $S$. algicida at consecutive samplings. The values of $t_{1}$ and $t_{2}$ used for calculation were 24 and $72 \mathrm{~h}$, respectively, which provided the highest specific growth rate.

Data for Stoeckeria algicida growth rate were fitted to a Michaelis-Menten equation:

$$
\mu=\frac{\mu_{\max }\left(x-x^{\prime}\right)}{K_{\mathrm{GR}}+\left(x-x^{\prime}\right)}
$$

where $\mu_{\max }$ is the maximum growth rate $\left(\mathrm{d}^{-1}\right), x$ is the prey concentration (cells ml-1 or $\mathrm{ng} \mathrm{C} \mathrm{ml}^{-1}$ ), $x^{\prime}$ is threshold prey concentration (where $\mu=0$ ), and $K_{\mathrm{GR}}$ is the prey concentration sustaining $1 / 2 \mu_{\max }$. Data were iteratively fitted to the model using DeltaGraph ${ }^{\circledR}$ (Delta Point).

Ingestion and clearance rates were calculated using the equations of Frost (1972) and Heinbokel (1978). Incubation times for calculating ingestion and clearance rates were the same as for estimating growth rate. Ingestion rate (IR) data for Stoeckeria algicida were fitted to a Michaelis-Menten equation: 


$$
\mathrm{IR}=\frac{I_{\max }(x)}{K_{\mathrm{IR}}+(x)}
$$

where $I_{\max }$ is the maximum ingestion rate (cells grazer $^{-1} \mathrm{~d}^{-1}$ or ng $\mathrm{C}$ grazer $\left.{ }^{-1} \mathrm{~d}^{-1}\right), x$ is the prey concentration (cells ml-1 or $\mathrm{ng} \mathrm{C} \mathrm{ml}^{-1}$ ), and $K_{\mathrm{IR}}$ is the prey concentration sustaining $1 / 2 I_{\max }$.

Gross growth efficiency (GGE). GGE, defined as grazer biomass produced (+) or lost (-) per prey biomass ingested, as a function of mean prey concentration, was calculated from estimates of carbon content per cell based on cell volume for each mean prey concentration.

Grazing impact. We estimated grazing coefficients attributable to Stoeckeria algicida on Heterosigma akashiwo by combining field data on the abundances of $S$. algicida and co-occurring prey with the ingestion rates of the predators on the prey obtained in the present study.

Grazing coefficients $\left(g, \mathrm{~h}^{-1}\right)$ were calculated as:

$$
g=(1 / \Delta t)\left\{\ln \left[C_{\mathrm{i}} /\left(C_{\mathrm{i}}-C_{\mathrm{e}}\right)\right]\right\}
$$

where $\Delta t(\mathrm{~h})$ is a time interval, $C_{\mathrm{e}}\left(\right.$ cells $\left.\mathrm{ml}^{-1}\right)$ is the number of prey cells eaten by the Stoeckeria algicida population in $1 \mathrm{ml}$ of seawater in $1 \mathrm{~h}$, and $C_{\mathrm{i}}\left(\right.$ cells ml $\mathrm{m}^{-1}$ ) is the initial cell concentration of prey for a given hour. The values of $C_{\mathrm{e}}$ were calculated as:

$$
C_{\mathrm{e}}=\mathrm{PIR} \times 1 \text { hour }=\mathrm{IR} \times G \times 1 \text { hour }
$$

where PIR is the population ingestion rate of $S$. algicida on Heterosigma akashiwo in $1 \mathrm{ml}$ of seawater (prey eaten $\mathrm{ml}^{-1} \mathrm{~h}^{-1}$ ), IR is the ingestion rate (prey eaten grazer $^{-1} \mathrm{~h}^{-1}$ ) of $S$. algicida on H. akashiwo, and $G$ is the abundance (grazers $\mathrm{ml}^{-1}$ ) of $S$. algicida at the same time as $C_{\mathrm{i}}$. IRs were corrected using $Q_{10}=2.8$ (Hansen et al. 1997) because in situ water temperatures and the temperature used in the laboratory for this experiment $\left(20^{\circ} \mathrm{C}\right)$ were different.

\section{RESULTS}

\section{Abundances and hydrography in Masan Bay}

Two red tides were dominated by Heterosigma akashiwo in Masan Bay between May and July 2004; the first red tide occurred between May 31 and June 8, and the second one occurred between July 10 and July 16 (Fig. 1). The maximum abundances of $H$. akashiwo in the first and second red tide periods were 58400 and 99200 cells ml $^{-1}$, respectively, while those of Stoeckeria algicida were 1130 and 17400 cells ml$^{-1}$, respectively.

Water temperatures and salinities in the surface waters in the first red tide period were 19.0 to $2.8^{\circ} \mathrm{C}$ and 24.7 to 29.4 psu, respectively, while those in the second red tide period were 23.7 to $26.0^{\circ} \mathrm{C}$ and 4.1 to 20.6 psu, respectively (Fig. 1). The $\mathrm{pH}$ values and DO concentrations in the surface waters in the first red tide period were 7.90 to 8.33 and 5.2 to $10.3 \mu \mathrm{M}$, respectively, while those in the second red tide period were 7.40 to 8.58 and 5.9 to $8.4 \mu \mathrm{M}$, respectively.

\section{Feeding process}

Stoeckeria algicida fed on Heterosigma akashiwo using a peduncle after anchoring the prey by a tow filament (Fig. 2). S. algicida deployed a tow filament to anchor a $H$. akashiwo cell. The distance between the predator cell and the prey cell was almost twice the prey cell length when the predator attached the tow filament to the prey cell, but reduced to be similar to the prey cell length before the peduncle deployed. The time lag (mean $\pm \mathrm{SE}$ ) between the deployment of a tow filament and a peduncle was $22 \pm 1 \mathrm{~s}(\mathrm{n}=5)$. The prey materials (reddish materials in Fig. 2) were moved in inside the predator cell through the peduncle. The time (mean $\pm \mathrm{SE}$ ) for a $H$. akashiwo cell to be completely fed on by a $S$. algicida cell after the predator deployed a peduncle to the prey cell was $129 \pm 4 \mathrm{~s}(\mathrm{n}=5)$. As the material of the prey cell was moved into the protoplasm of the predator, the size of the prey cell was reduced, while the size of the predator increased. Eventually, round (1 to $2 \mu \mathrm{m}$ ) transparent fecal material remained at the end of this feeding. Up to 5 S. algicida cells were observed to deploy their peduncles to a H. akashiwo cell simultaneously.

\section{Growth rates}

Stoeckeria algicida grew well on Heterosigma akashiwo. The specific growth rates of the heterotrophic dinoflagellate increased rapidly with increasing mean prey concentration before saturating at H. akashiwo concentrations of ca. $350 \mathrm{ng} \mathrm{C} \mathrm{ml}^{-1}$ (3500 cells $\mathrm{ml}^{-1}$ ) (Fig. 3). When the data were fitted to Eq. (2), the maximum specific growth rate $\left(\mu_{\max }\right)$ of $S$. algicida was $1.63 \mathrm{~d}^{-1}$. A threshold prey concentration (where net growth $=0$ ) for $S$. algicida was $1.9 \mathrm{ng} \mathrm{C} \mathrm{ml}^{-1}$ $\left(19\right.$ cells $\left.\mathrm{ml}^{-1}\right)$.

\section{Ingestion and clearance rates}

The ingestion rates of Stoeckeria algicida on a unialgal diet of Heterosigma akashiwo increased with increasing mean prey concentration (Fig. 4). When the 

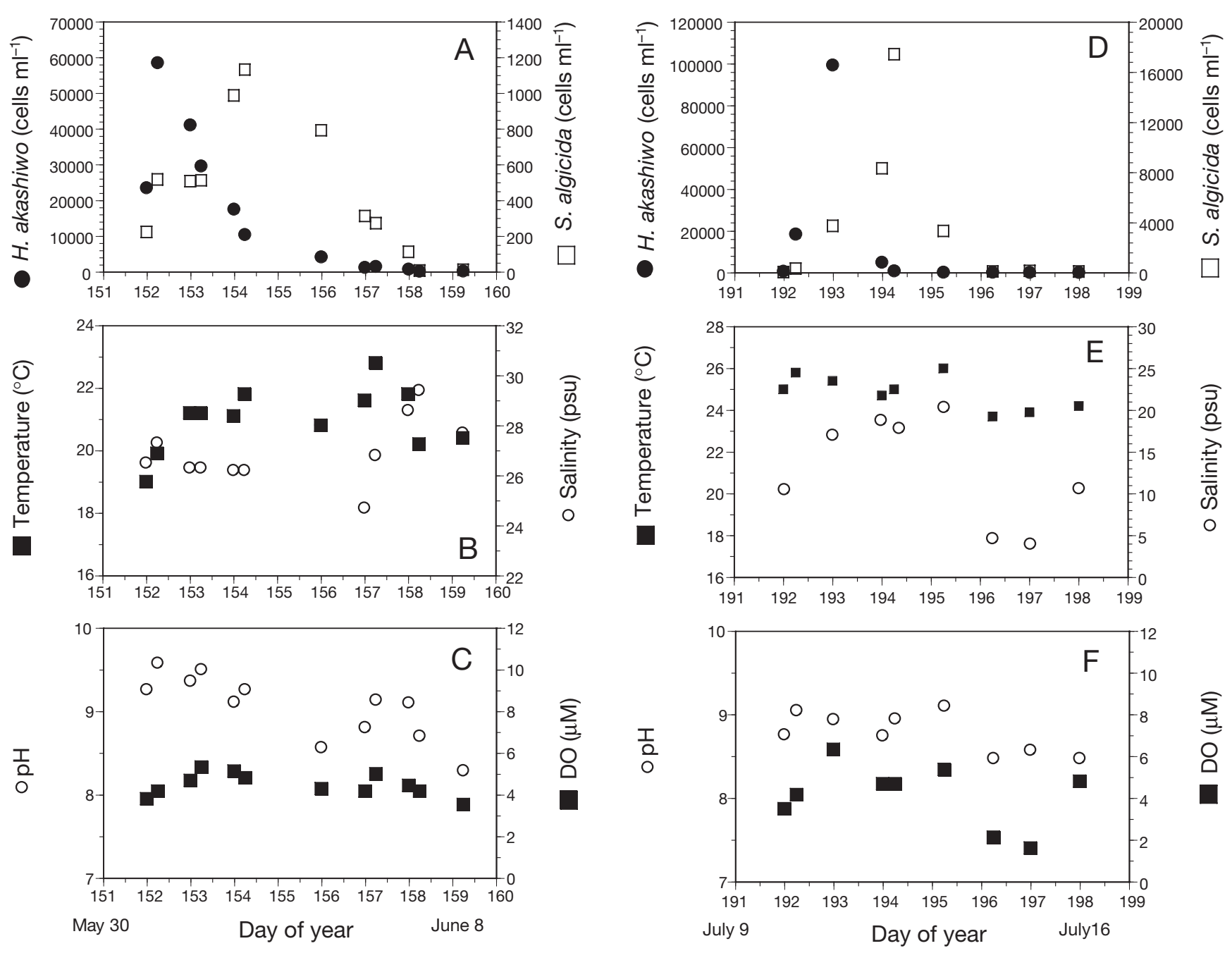

Fig. 1. Abundances of $(\mathrm{A}, \mathrm{D})$ Heterosigma akashiwo and Stoeckeria algicida, $(\mathrm{B}, \mathrm{E})$ water temperature and salinity, and $(\mathrm{C}, \mathrm{F}) \mathrm{pH}$ and dissolved oxygen concentration (DO) at a pier in Masan Bay, Korea, in the first $H$. akashiwo red tide period (from May 31 to June 8, 2004) and in the second H. akashiwo red tide period (from July 10 to July 16, 2004)

data were fitted to Eq. (3), the maximum ingestion rate of $S$. algicida was $0.75 \mathrm{ng}$ C grazer ${ }^{-1} \mathrm{~d}^{-1}$ (7.5 prey cells grazer $^{-1} \mathrm{~d}^{-1}$ ).

The maximum clearance rate of Stoeckeria algicida on Heterosigma akashiwo was $3.7 \mu$ grazer $^{-1} \mathrm{~h}^{-1}$ at the lowest mean prey concentration of $1 \mathrm{ng} \mathrm{C} \mathrm{ml}^{-1}$ and the maximum volume-specific clearance rate of $S$. algicida was $9.7 \times 10^{6} \mathrm{~h}^{-1}$.

\section{Cell volume}

After $72 \mathrm{~h}$ incubation, the cell volume of Stoeckeria algicida-fed Heterosigma akashiwo at the low mean prey concentrations of 1.0 to $1.8 \mathrm{ng} \mathrm{C} \mathrm{ml}^{-1}$ (320 to $380 \mathrm{\mu m}^{3}$ ) was slightly larger than that of $S$. algicida without added prey $\left(300 \mathrm{\mu m}^{3}\right)$, but at the higher prey concentration, cell volume increased continuously from 570 to $1350 \mathrm{\mu m}^{3}$ with increasing mean prey concentration (Fig. 5). The largest cell volume of $S$. algicida measured in these experiments $\left(2520 \mu^{3}\right)$ was approximately 20 times larger than the smallest one $\left(130 \mathrm{\mu m}^{3}\right)$.

The cell volume of Stoeckeria algicida where the maximum volume-specific clearance rate was obtained was $380 \mu^{3}$.

\section{Gross growth efficiency}

GGE of Stoeckeria algicida on Heterosigma akashiwo were negative for mean prey concentrations $\leq 4 \mathrm{ng}$ $\mathrm{C} \mathrm{ml}{ }^{-1}$, but efficiencies increased up to $79 \%$ with increasing mean prey concentration (Fig. 6). 

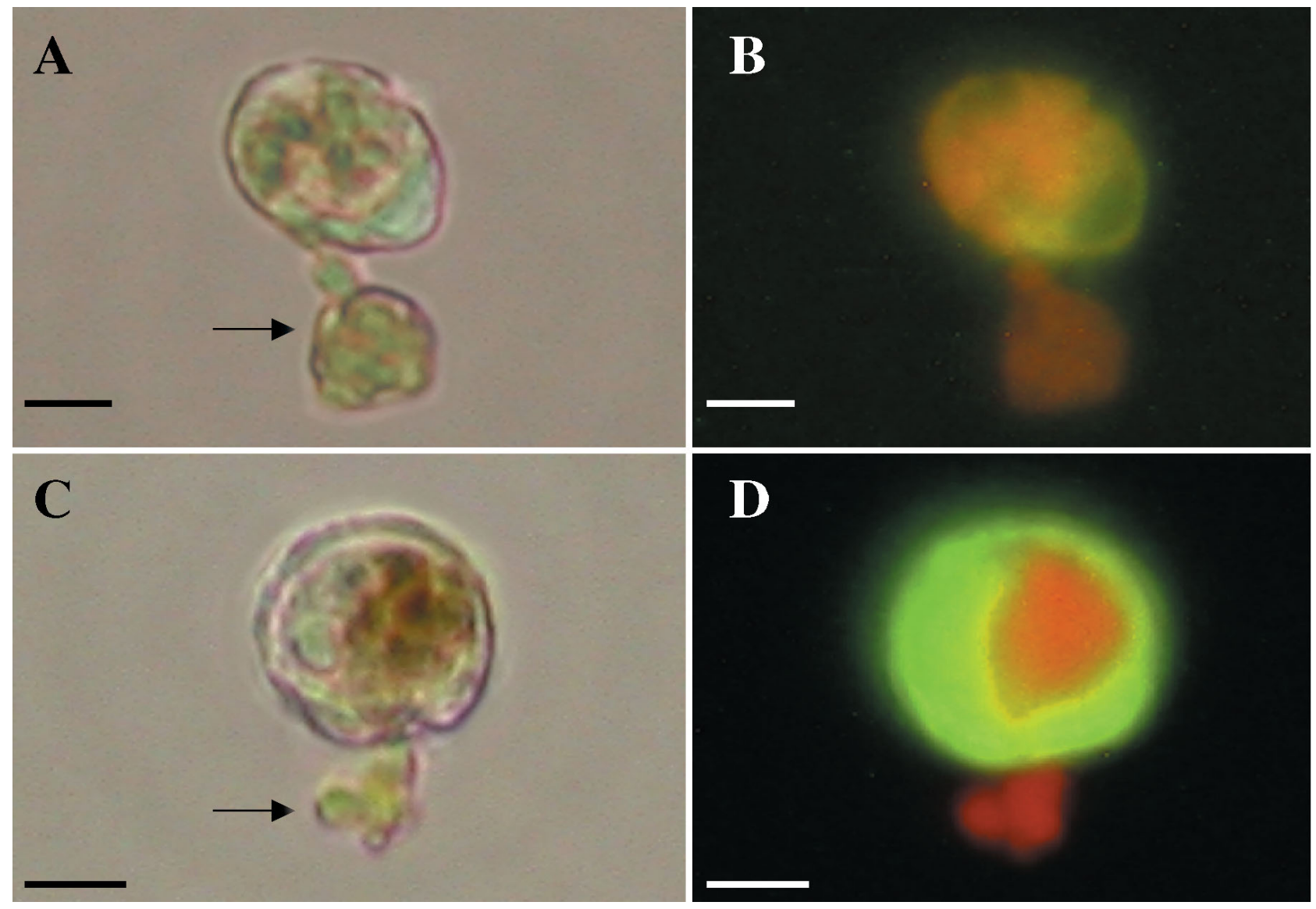

Fig. 2. Feeding by Stoeckeria algicida on a Heterosigma akashiwo cell using a peduncle. (A,B) Lateral view. (C,D) Anterior view. (A) and (C) are phase photomicrographs and (B) and (D) are photomicrographs taken using epifluorescence. Reddish colors in (B) and (D) are prey materials. Arrows indicate prey cells. All prey and predator cells are the same cells in all panels. Scale bars $=5 \mu \mathrm{m}$

\section{Grazing impact}

Grazing coefficients attributable to Stoeckeria algicida on co-occurring Heterosigma akashiwo in Masan Bay, Korea, were up to $1.63 \mathrm{~h}^{-1}$ with 2 exceptional values at the decline stages of the red tides dominated by $H$. akashiwo; one value of $g$ was $8.5 \mathrm{~h}^{-1}$ when the concentrations of $H$. akashiwo and S. algicida were 700 and 17400 cells ml ${ }^{-1}$, respectively, and another value of $g$ was $4.0 \mathrm{~h}^{-1}$ when the concentrations of $H$. akashiwo and $S$. algicida were 45 and 3300 cells mll, respectively (Fig. 7, Table 1). In general, $g$ increased with increasing $S$. algicida concentration.

\section{DISCUSSION}

\section{Abundances in Masan Bay}

The abundance of Stoeckeria algicida in Masan Bay between May and July 2004 peaked 1 to $2 \mathrm{~d}$ after that of Heterosigma akashiwo. Water masses in the sam- pling location might be advected over sampling intervals even though the circulation of water masses inside Masan Bay is restricted. If the advection were very small, the time lags between the abundance peaks of $H$. akashiwo and S. algicida in these first and second red tide periods could be calculated to be 1 to $2 \mathrm{~d}$.

\section{Feeding mechanism}

Stoeckeria algicida feeds on Heterosigma akashiwo using a peduncle after anchoring the prey by a tow filament. Peduncle feeders feed on diverse prey species with a wide size range because they are able to feed on prey larger than themselves (Biecheler 1952, cited by Hansen 1991b, Lee 1977, Spero 1982, Hansen 1991a,b, Burkholder \& Glasgow 1995). For example, Pfiesteria spp. are known to feed on diverse prey items including algae, ciliates, and rotifers (Burkholder \& Glasgow 1995). It is, therefore, worthwhile exploring the kinds of prey species used when diverse prey items are provided to $S$. algicida. 


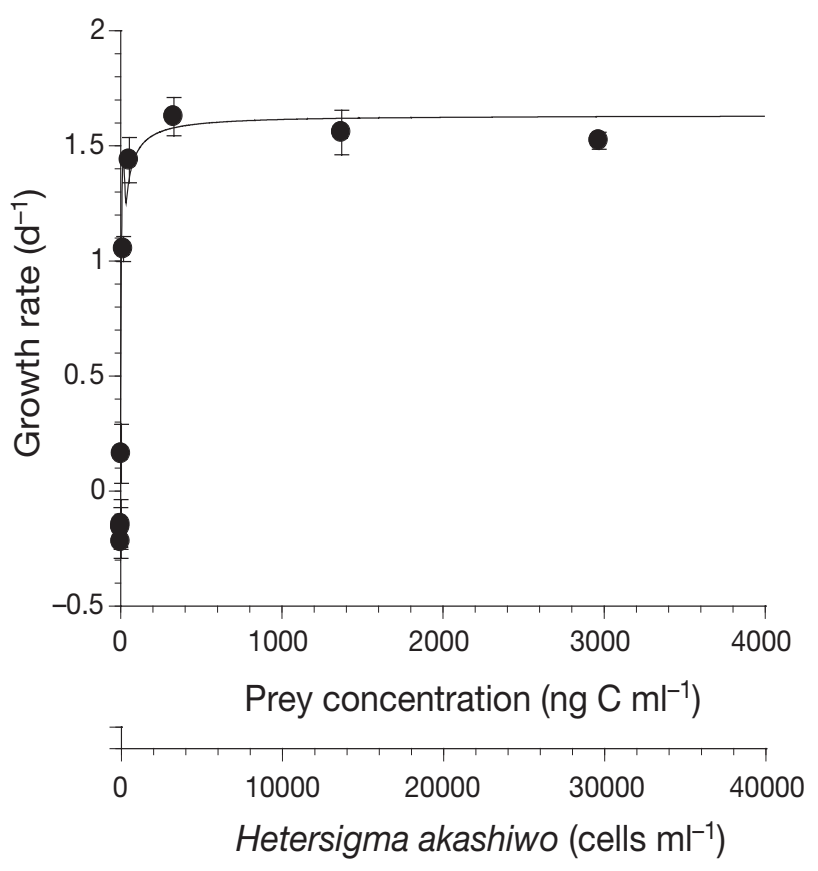

Fig. 3. Specific growth rates of Stoeckeria algicida on Heterosigma akashiwo as a function of mean prey concentration $\left(x, \mathrm{ng} \mathrm{C} \mathrm{ml}{ }^{-1}\right)$. Symbols represent treatment means $\pm 1 \mathrm{SE}$. The curve is fitted by a Michaelis-Menten equation (Eq. 2) using all treatments in the experiment. Growth rate (GR, $\left.\mathrm{d}^{-1}\right)=1.63\{(x-1.9) /[11.6+(\mathrm{x}-1.9)]\}, \mathrm{r}^{2}=0.947$

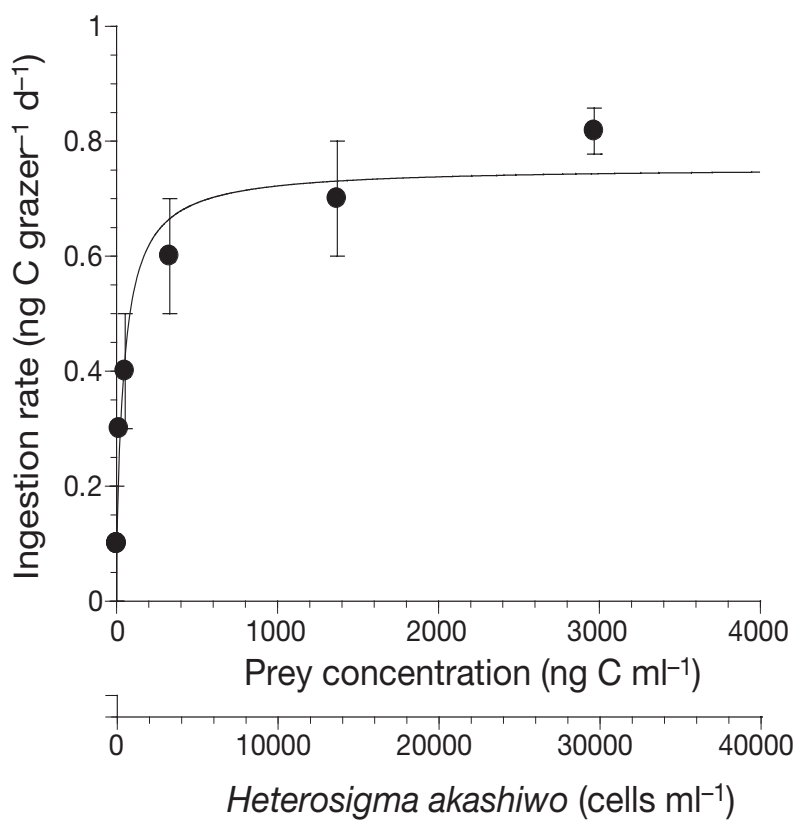

Fig. 4. Ingestion rates of Stoeckeria algicida on Heterosigma akashiwo as a function of mean prey concentration $(x)$. Symbols represent treatment means $\pm 1 \mathrm{SE}$. The curve is fitted by a Michaelis-Menten equation (Eq. 3) using all treatments in the experiment. Ingestion rate $\left(\mathrm{IR}, \mathrm{ng} \mathrm{C}\right.$ grazer $\left.^{-1} \mathrm{~d}^{-1}\right)=0.75$ $[x /(45.3+x)], r^{2}=0.915$

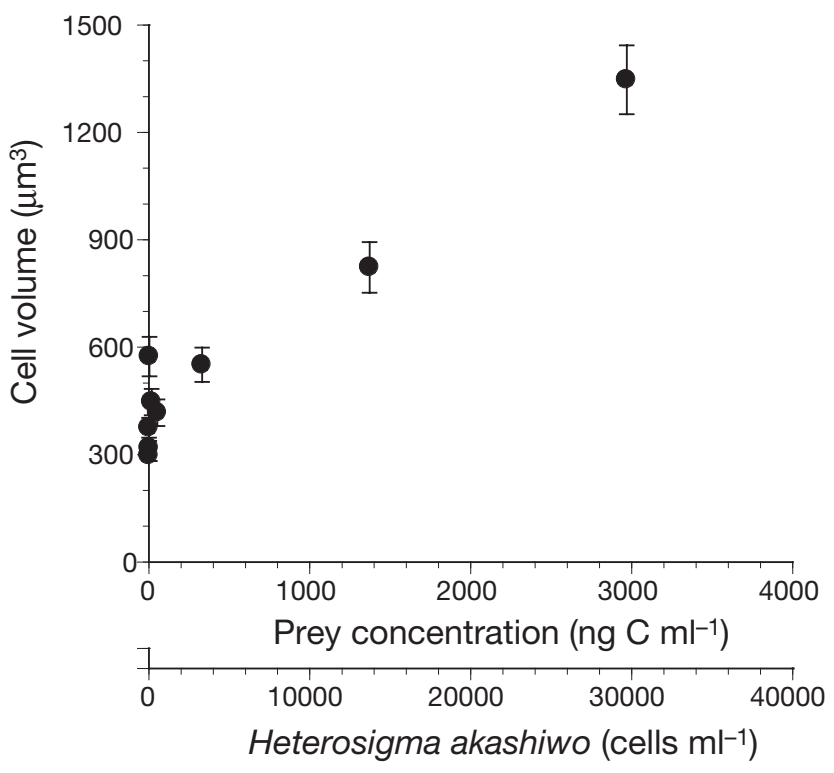

Fig. 5. Cell volume of Stoeckeria algicida on Heterosigma akashiwo after $72 \mathrm{~h}$ incubation as a function of mean prey concentration. Symbols represent treatment means $\pm 1 \mathrm{SE}$

\section{Protistan predators on Heterosigma akashiwo}

Stoeckeria algicida grew well on Heterosigma akashiwo in the present study. Only a few heterotrophic protists are known to grow on $H$. akashiwo, e.g. the heterotrophic dinoflagellates Gyrodinium dominans and Oxyrrhis marina, and the prostomatid ciliate Tiarina fusus (Nakamura et al. 1995, Jeong et al. 2002, 2003). However, the large tintinnid ciliate Favella taraikaensis did not ingest this prey (Taniguchi \& Takeda 1988) or the ingestion rate was undetectable even though this prey was ingested in the initial incubation (Kamiyama \& Arima 2001). S. algicida is, therefore, one of the few heterotrophic dinoflagellate grazers so far reported to grow on $H$. akashiwo.

\section{Growth and ingestion}

The maximum growth rate of Stoeckeria algicida on Heterosigma akashiwo in the present study $\left(1.63 \mathrm{~d}^{-1}\right)$ was higher than that of any other protistan grazer on the same prey so far reported (Table 2), when corrected to $20^{\circ} \mathrm{C}$ using $Q_{10}=2.8$ (Hansen et al. 1997).

The maximum ingestion rate of Stoeckeria algicida on Heterosigma akashiwo in the present study $(0.75 \mathrm{ng}$ C grazer ${ }^{-1} \mathrm{~d}^{-1}$ ) was lower than that of any other protistan grazer on the same prey so far reported (Table 2). The smaller volume of $S$. algicida might be responsible for its higher growth, despite lower ingestion rates on H. akashiwo compared to those of Oxyrrhis marina and Tiarina fusus. 


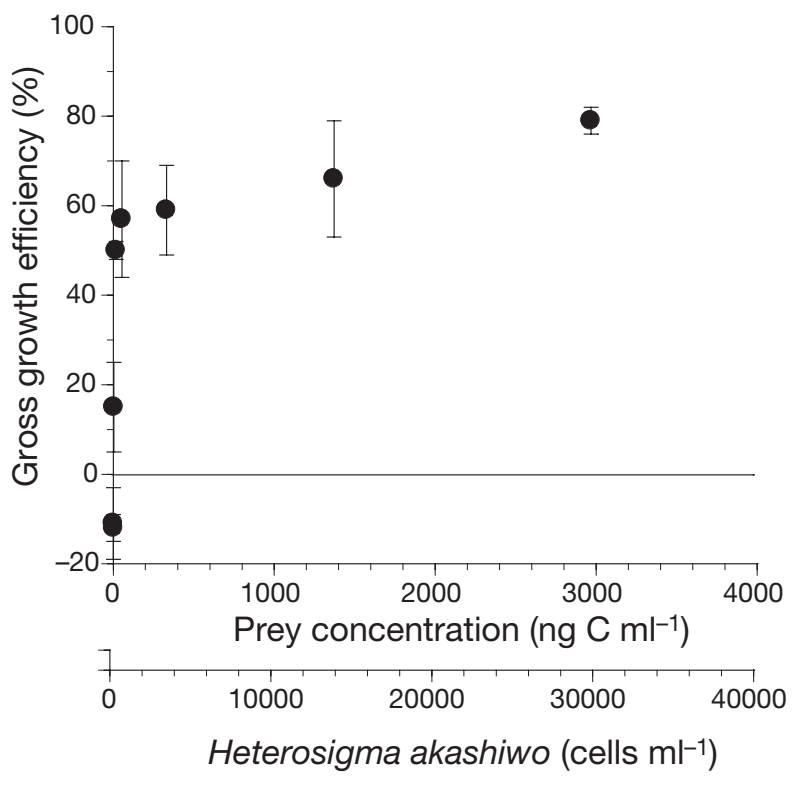

Fig. 6. Gross growth efficiency (GGE), defined as Stoeckeria algicida biomass produced (+) or lost (-) per Heterosigma akashiwo biomass ingested, as a function of mean prey concentration. Symbols represent treatment means $\pm 1 \mathrm{SE}$

The maximum clearance rate of Stoeckeria algicida on Heterosigma akashiwo (3.7 $\mu$ grazer $\left.^{-1} \mathrm{~h}^{-1}\right)$ was much higher than that of any other protistan grazer on the same prey so far reported (Table 2). S. algicida, which feeds on prey cells using a peduncle, might capture and ingest $H$. akashiwo more efficiently at low prey concentration than Oxyrrhis marina and Tiarina fusus, which feed on prey cells by engulfment.

The maximum volume-specific clearance rate of Stoeckeria algicida on Heterosigma akashiwo $(9.7 \times$ $10^{6} \mathrm{~h}^{-1}$ ) is higher than that for any other heterotrophic dinoflagellate on phytoplankton. Before the present study, the maximum volume-specific clearance rate of Protoperidinium bipes on Skeletonema costatum

Table 2. Comparison of growth, ingestion and clearance rates of Stoeckeria algicida and other protists on Heterosigma akashiwo. Rates are corrected to $20^{\circ} \mathrm{C}$ using $Q_{10}=2.8$ (Hansen et al. 1997). PV: predators' volume as $\times 10^{3}{\mu m^{3}}_{;} ; \mu_{\max }$ : maximum growth rate $\left(\mathrm{d}^{-1}\right) ; I_{\max }$ : maximum ingestion rate $\left(\mathrm{ng} \mathrm{C}\right.$ predator $\left.{ }^{-1} \mathrm{~d}^{-1}\right)$; $C_{\max }$ : maximum clearance rate $\left(\mu \mathrm{l}\right.$ predator $\left.^{-1} \mathrm{~h}^{-1}\right)$; HTD: heterotrophic dinoflagellate; NC: naked ciliate

\begin{tabular}{|lccccl|}
\hline Predator & PV & $\mu_{\max }$ & $I_{\max }$ & $C_{\max }$ & Source \\
\hline Stoeckeria algicida (HTD) & 1.4 & 1.62 & 0.75 & 3.7 & this study \\
Oxyrrhis marina (HTD) & 2.6 & 1.43 & 1.25 & 0.3 & Jeong et al. (2003) \\
Gyrodinium dominans (HTD) & 4.0 & 0.15 & & & Nakamura et al. (1995) \\
Tiarina fusus (NC) & 25.4 & 0.12 & 7.2 & 0.7 & Jeong et al. (2002) \\
\hline
\end{tabular}

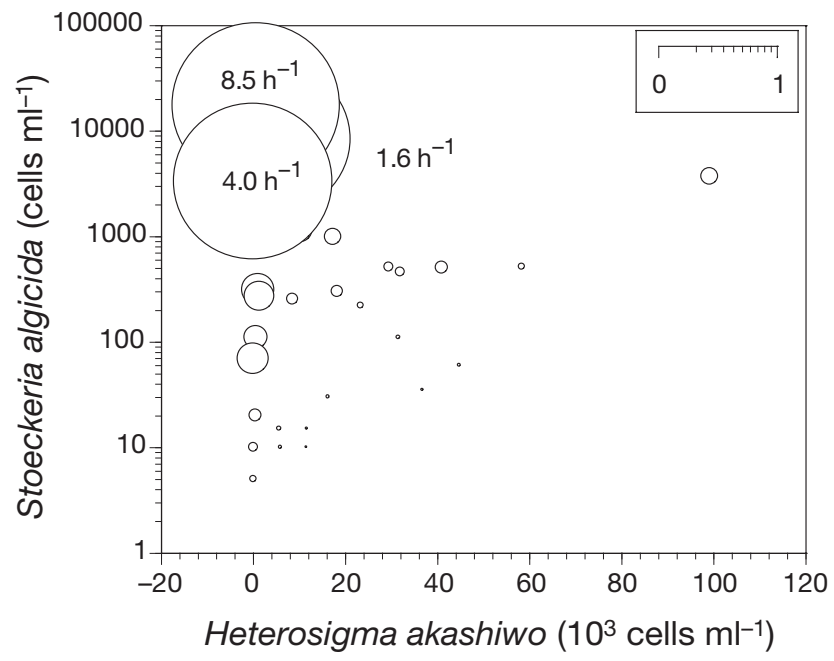

Fig. 7. Calculated grazing coefficients $\left(g, \mathrm{~h}^{-1}\right)$ attributable to Stoeckeria algicida on Heterosigma akashiwo (see text for calculation), $\mathrm{n}=30$. The scale of all circles except 2 circles in the inset box is $g\left(\mathrm{~h}^{-1}\right)$. The value of $g$ for one circle was $8.5 \mathrm{~h}^{-1}$ when the concentrations of $H$. akashiwo and S. algicida were 700 and 17400 cells ml ${ }^{-1}$, while the value of $g$ for the other circle was $4.0 \mathrm{~h}^{-1}$ when the concentrations of $H$. akashiwo and $S$. algicida were 45 and 3300 cells $\mathrm{ml}^{-1}$, respectively. The scales for these 2 values of $g$ were reduced

$\left(5.4 \times 10^{6} \mathrm{~h}^{-1}\right)$ had been the highest value reported (Jeong et al. 2004). The higher maximum clearance rate of $S$. algicida on $H$. akashiwo $\left(3.7 \mu\right.$ grazer $^{-1} \mathrm{~h}^{-1}$ ) compared with that of $P$. bipes on $S$. costatum $(1.0 \mu \mathrm{l}$ grazer $^{-1} \mathrm{~h}^{-1}$ ) was responsible for its higher maximum volume-specific clearance rate because the cell volume of the former grazer, where the maximum volume-specific clearance rate was obtained $\left(380 \mu^{3}\right)$, was larger than that of the latter grazer $\left(184 \mu^{3}\right)$. $S$. algicida, might capture and ingest $H$. akashiwo more efficiently at low prey concentration than $P$. bipes, which feeds on prey cells using a feeding veil (pallium).

The maximum GGE of Stoeckeria algicida on Heterosigma akashiwo (79\%) was higher than that for the obligately heterotrophic dinoflagellate Protoperiidnium huberi on the diatom Ditylum brightwelli (59\%), the highest value among the Protoperiidnium species so far reported (Buskey et al. 1994). Additional experiments confirmed this high GGE. Like Pfiesteria spp., which are also peduncle feeders, mixotrophic growth using kleptoplastids might be partially responsible for this high GGE (Lewitus et al. 1999). Alternatively, the carbon content for a $H$. akashiwo cell might be somewhat underestimated and/or that for a $S$. algicida cell overestimated. 


\section{Grazing impact}

Grazing coefficients attributable to Stoeckeria algicida on co-occurring Heterosigma akashiwo in Masan Bay, Korea, were up to $1.63 \mathrm{~h}^{-1}$ (i.e. $80 \%$ of $H$. akashiwo populations were removed by a $S$. algicida population in $1 \mathrm{~h}$ ), with 2 exceptional values at the decline stages of the red tides dominated by $H$. akashiwo. When the $S$. algicida populations are very high and the H. akashiwo populations are very low, grazing impact can be so high that grazing has the potential to remove almost all prey cells within hours (Fig. 7, Table 1). Populations of $S$. algicida may, therefore, have considerable grazing impact on populations of $H$. akashiwo and contribute to the decline of red tides dominated by H. akashiwo.

Acknowledgements. We thank Yeong Du Yoo and Nam Seon Kang for technical support. This paper was funded by a NRL grant from MOST \& KISTEP (M1-0302-00-0068).

\section{LITERATURE CITED}

Biecheler B (1952) Recherches sur les peridiniens. Bull Biol Fr Belg Suppl 36:1-149

Burkholder JM, Glasgow HB Jr (1995) Interactions of a toxic estuarine dinoflagellate with microbial predators and prey. Arch Protistenkd 145:177-188

Buskey EJ, Coulter CJ, Brown SL (1994) Feeding, growth and bioluminescence of the heterotrophic dinoflagellate Protoperidinium huberi. Mar Biol 121:373-380

Chang FH, Pridmore R, Boustead N (1993) Occurrence and distribution of Heterosigma cf. akashiwo (Raphidophyceae) in a 1989 bloom in Big Glory Bay, New Zealand. In: Smayda TJ, Shimizu Y (eds) Toxic phytoplankton blooms in the sea. Elsevier, Amsterdam, p 675-680

ECOHAB (1995) The ecology and oceanography of harmful algal blooms. A national research agenda. Woods Hole Oceanographic Institute, Woods Hole, MA, p 1-66

Eppley RW, Harrison WG (1975) Physiological ecology of Gonyaulax polyedrum, a red tide water dinoflagellate of southern California. In: Locicero VR (ed) Proceedings First International Conference on Toxic Dinoflagellate Blooms. Massachusetts Science and Technology Foundation, Wakefield, MA, p 11-22

Frost BW (1972) Effects of size and concentration of food particles on the feeding behavior of the marine planktonic copepod Calanus pacificus. Limnol Oceanogr 17:805-815

Guillard RRL, Ryther JH (1962) Studies of marine planktonic diatoms. I. Cyclotella nana Hustedt and Detonula confervacea (Cleve) Grun. Can J Microbiol 8:229-239

Hansen PJ (1991a) Dinophysis - a planktonic dinoflagellate genus which can act both as a prey and a predator of a ciliate. Mar Ecol Prog Ser 69:201-204

Hansen PJ (1991b) Quantitative importance and trophic role of heterotrophic dinoflagellates in a coastal pelagic food web. Mar Ecol Prog Ser 73:253-261

Hansen PJ, Bjornsen PK, Hansen BW (1997) Zooplankton grazing and growth: scaling within the $2-2000-\mu \mathrm{m}$ body size range. Limnol Oceanogr 42:687-704

Heinbokel JF (1978) Studies on the functional role of tintinnids in the Southern California Bight. I. Grazing and growth rates in laboratory cultures. Mar Biol 47:177-189
Holmes RW, Williams PM, Eppley RW (1967) Red water in La Jolla Bay, 1964-1966. Limnol Oceanogr 12:503-512

Honjo T (1993) Overview on bloom dynamics and physiological ecology of Heterosigma akashiwo. In: Smayda T, Shimizu Y (eds) Toxic phytoplankton blooms in the sea. Elsevier, Amsterdam, p 33-41

Imai I, Itakura S, Yamaguchi M, Honjo T (1996) Selective germination of Heterosigma akashiwo (raphidophyceae) cysts in bottom sediments under low light conditions: a possible mechanism of red tide initiation. In: Yasumoto T, Oshima Y, Fukuyo Y (eds) Harmful and toxic algal blooms. UNESCO, Paris, p 197-200

Jeong HJ (1995) The interactions between microzooplanktonic grazers and dinoflagellates causing red tides in the open coastal waters off southern California. PhD thesis, University of California, San Diego, CA

Jeong HJ (1999) The ecological roles of heterotrophic dinoflagellates in marine planktonic community. J Eukaryot Microbiol 46:390-396

Jeong HJ, Yoon JY, Kim JS, Yoo YD, Seong KA (2002) Growth and grazing rates of the prostomatid ciliate Tiarina fusus on red-tide and toxic algae. Aquat Microb Ecol 28:289-297

Jeong HJ, Kim JS, Yoo YD, Kim ST and 6 others (2003) Feeding by the heterotrophic dinoflagellate Oxyrrhis marina on the red-tide raphidophyte Heterosigma akashiwo: a potential biological method to control red tides using mass-cultured grazers. J Eukaryot Microbiol 50:274-282

Jeong HJ, Yoo YD, Kim ST, Kang NS (2004) Feeding by the heterotrophic dinoflagellate Protoperidinium bipes on the diatom Skeletonema costatum. Aquat Microb Ecol 36:171-179

Jeong HJ, Kim JS, Park JY, Kim JH and 5 others (2005) Stoeckeria algicida n. gen., n. sp. (Dinophayceae) from the coastal waters off southern Korea: morphology and small subunit ribosomal DNA gene sequence. J Eukaryot Microbiol (in press)

Johnson MD, Rome M, Stoecker DK (2003) Microzooplankton grazing on Prorocentrum minimum and Karlodinium micrum in Chesapeake Bay. Limnol Oceanogr 48:238-248

Kamiyama T, Arima S (2001) Feeding characteristics of two tintinnid ciliate species on plankton including harmful species: effects of prey size on ingestion rates and selectivity. J Exp Mar Biol Ecol 257:281-296

Kamiyama T, Itakura S, Nagasaki K (2000) Changes in microbial loop components: effects of a harmful algal bloom formation and its decay. Aquat Microb Ecol 21:21-30

Kim JS, Jeong HJ (2004) Feeding by the heterotrophic dinoflagellates Gyrodinium dominans and G. spirale on the red-tide dinoflagellate Prorocentrum minimum. Mar Ecol Prog Ser 280:85-94

Lee RE (1977) Saprophytic and phagotrophic isolates of the colorless heterotrophic dinoflagellate Gyrodinium lebouriae Herdman. J Mar Biol Assoc UK 57:303-315

Lewitus AJ, Glasgow HB Jr, Burkholder JM (1999) Kleptoplastidy in the toxic dinoflagellate Pfiesteria piscicida (Dinophyceae). J Phycol 35:303-312

MacKenzie L (1991) Toxic and noxious phytoplankton in Big Glory Bay, Stewart Island, New Zealand. J Appl Phycol 3: 19-34

Menden-Deuer S, Lessard E (2000) Carbon to volume relationships for dinoflagellates, diatoms, and other protist plankton. Limnol Oceanogr 45:569-579

Nagasaki K, Itakura S, Imai I, Nakagiri S, Yamaguchi M (1996) The disintegration process of a Heterosigma akashiwo (raphidophyceae) red tide in northern Hirosima Bay, Japan, during the summer of 1994. In: Yasumoto T, Oshima Y, Fukuyo Y (eds) Harmful and toxic algal blooms. UNESCO, Paris, p 251-254 
Nakamura Y, Suzuki SY, Hiromi J (1995) Growth and grazing of a naked heterotrophic dinoflagellate, Gyrodinium dominans. Aquat Microb Ecol 9:157-164

Spero HJ (1982) Phagotrophy in Gymnodinium fungiforme (Pyrrhophyta): the peduncle as an organelle of ingestion. J Phycol 18:356-360

Stoecker DK, Gustafson DE (2002) Predicting grazing mortality of an estuarine dinoflagellate, Pfiesteria piscicida. Mar Ecol Prog Ser 233:31-38

Strathmann RR (1967) Estimating the organic carbon content of phytoplankton from cell volume or plasma volume.

Editorial responsibility: Evelyn \& Barry Sherr (Contributing Editors), Corvallis, Oregon, USA
Limnol Oceanogr 12:411-418

Taniguchi A, Takeda Y (1988) Feeding rate and behavior of the tintinnid ciliate Favella taraikaensis observed with a high speed VTR system. Mar Microb Food Webs 3:21-34

Tillmann U (2004) Interactions between planktonic microalgae and protozoan grazers. J Eukaryot Microbiol 51: 156-168

Watras CJ, Garcon VC, Olson RJ, Chishom SW, Anderson DM (1985) The effect of zooplankton grazing on estuarine blooms of the toxic dinoflagellate Gonyaulax tamarensis. J Plankton Res 7:891-908

Submitted: June 11, 2004; Accepted: February 17, 2005 Proofs received from author(s): June 2, 2005 